NBSIR 80-2017

\title{
State Standards, Plans and Programs for Energy Conservation of Consumer Products
}

Sophie J. Chumas

Office of Standards Information, Analysis, and Development National Engineering Laboratory National Bureau of Standards U.S. Department of Commerce Washington, D.C. 20234

January 1980

Issued April 1980

Prepared for

Division of Operational and Environmental Safety $-Q C \longrightarrow$ Nepartment of Energy

100

.456 



\section{STATE STANDARDS, PLANS AND PROGRAMS FOR ENERGY CONSERVATION OF CONSUMER PRODUCTS}

Sophie J. Chumas

Office of Standards Information,

Analysis, and Development National Engineering Laboratory National Bureau of Standards U.S. Department of Commerce Washington, D.C. 20234

January 1980

Issued April 1980

Prepared for

Division of Operational and

Environmental Safety

Department of Energy

Washington, D.C. 20545

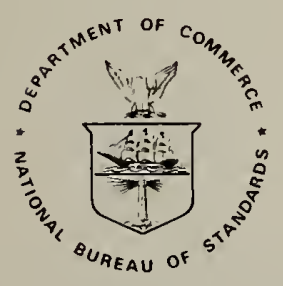

U.S. DEPARTMENT OF COMMERCE, Philip M. Klutznick, Secretary Luther H. Hodges, Jr., Deputy Secretary Jordan J. Baruch, Assistant Secretary for Productivity, Technology, and Innovation NATIONAL BUREAU OF STANDARDS, Ernest Ambler, Director 

CONTENTS

Preface . . . . . . . . . . . iv

Abstract .............. . v

Introduction ............. . . vi

State Responses . . . . . . . . . . 1

Bibliography - Introduction . . . . . 51

Bibliography . . . . . . . . . 52 


\section{Preface}

The Department of Energy, Division of Operational and Environmental Safety (DoE/OES) task directive was to provide an index of energy conservation-related standards from which any standards concerned with environmental, health and safety aspects could be recognized. The state inquiry was conducted to obtain information on standards for all energy conservation product-related me asures.

This document furnishes the state energy conservation standards information relating to consumer products. In addition to the conclusions evidenced by this document, a bibliographic key-word-in-context (KWIC) listing, "KWIC Index of Standards for Energy Conservation of Selected Product-Related Measures" (draft copy), was provided to DoE/OES. The KWIC index contained existing engineering standards and regulations issued by the U.S. private sector, the Federal Government, and foreign organizations. These two documents were in response to one section of the Interagency Agreement. 


\section{ABSTRACT}

States are responding to federal requirements to develop procedures for public energy conservation measures and plans affecting the states. This document furnishes evidence of, or absence of, state legislation, regulations, voluntary standards, $p l a n s$, and programs for energy conservation of consumer products. It also identifies the states that are participating in the pilot program Energy Extension Service (EES). The survey was based on seven questions asked of each state. This document contains the state responses to the inquiry and a bibliography of the materials submitted in response to the survey. 


\section{Introduction}

The Energy Conservation and Production Act of 1976 (ECPA), PL 94-385, instructed the state energy agencies to develop procedures for public energy conservation measures and energy conservation plans. National energy policy and conservation plans were identified by that Act, its predecessor (PL 94-163), the subsequent Act (PL 95-619), and the Federal Register.

The purpose of this document is to identify any state energy conservation legis lation, regulations, voluntary standards, plans, and programs issued for the conservation of energy used by consumer products. The consumer products specifically identified in PL 94-163, Section 322 are: "(1) Refrigerators and refrigerator-freezers (2) Freezers (3) D ishwashers (4) Clothes dryers (5) Water heaters (6) Room air conditioners (7) Home heating equipment, not including furnaces (8) Television sets (9) Kitchen ranges and ovens (10) Clothes washers (11) Humidifiers and dehumidifiers (12) Central air conditioners (13) Furnaces (14) Any other type of consumer product which the Administrator class ifies as a covered product under subsection (b)."

This document furnishes evidence of, or 1 ack of, state energy standards and plans for consumer products and education. It also serves to identify state participation in the pilot Energy Extension Service. EES is a program supported by a grant from the U.S. Department of Energy (DoE).

Specifically, the inquiry was based on the following questions:

1. a. Has the state passed enabling legis lation regarding energy conservation standards for consumer products?

b. Have state regulatory standards been written as a result of any legislation? What are they?

c. Which state agency has the regulatory authority?

d. Which state agency is responsible for enforcing the regulations? What is the enforcement procedure, if any?

2. Is the state planning to pass enabling legislation or is the state waiting for the Federal standards to be issued? 
3. Does the state have, or is it developing, any voluntary energy conservation and efficiency type standards for consumer products?

4. Does the state energy plan include public awareness programs regarding energy conservation and efficiency standards for consumer products?

Each state was asked to send any available literature in response to questions 1. (b) and (d), and 4 .

In addition to state responses, this document provides a state contact for consumer legis lative-type inquiries. It also provides a bibliography of the states existing legislation and the publications resulting from plans and programs for the conservation of energy used by consumer products. The bibliography consists only of those state materials submitted to the National Bureau of Standards, Office of $S$ tandards Information, Analysis, and Development, as a result of the inquiry. A few state officials mentioned that additional state plans may be found on file at DoE.

Excluded from this document are questions on energy conservation that fall in the subject-areas of solar energy and all other renewable energy sources; housing and building including the building codes; state procurement policies and standards; automobiles; and decorative lighting. Information in the subject-area of housing and buildings is covered by a three-parts-in-one document, "States' Energy Conservation Standards for New Housing and Buildings: (1) Status of Regulatory Activities; (2) Development, Administration and Enforcement Processes; and (3) State Legislative Analys is," issued by the National Institute of Building Sciences, Washington, D.C., 1978.

The survey identified nine states -- California, Hawai, Iowa, Michigan, Minnesota, Nevada, New Jersey, New York, and Wisconsin -- as having legis lation on energy conservation relating to consumer products. Nevada has not issued any regulations to date although it passed enabling legislation authorizing the State's Department of Energy to promulgate regulations prohibiting the sale of appliances with standing pilot lights.

The state responses are in the same sequential order as the inquiry questions. 


\section{ALABAMA}

- No enabling state legislation regarding energy conservation standards for consumer products

- Waiting for Federal standards to be is sued

- No voluntary energy conservation standards for consumer products

- Plans and Programs - As a participant in the Energy Extension Service (EES) program, a pilot project sponsored by the U.S. Department of Energy, the Alabama Energy Management Board used DOE/EES materials in informing people about the energy efficiency ratios of various consumer products.

Contact: Edwin G. Hudspeth

Staff Director

Al abama Energy Management Board

Al abama Development office

3734 At lanta Highway

Montgomery, A 1 abama 36130

Telephone: (205) 832-5010

NOTE: A disclosure system for various energy-consuming devices was proposed by the Alabama Energy Management Board but was met with opposition from builders and real estate dealers. A final copy of the disclosure form is being developed, however, and will be available upon request to any citizen interested in comparing the annual operating costs of a home's heat pumps, furnaces, air conditioners, refrigerators, stoves, etc., to the operating costs of other systems. 
- No enabling state legislation regarding energy conservation standards for consumer products

- Waiting for Federal standards to be issued

- No voluntary energy conservation standards for consumer products

- Plans and Programs - The Alaska State Energy Plan does not include specific programs regarding consumer products.

Contact: Clarissa M. Quinlan

Director

Alaska State Energy Office

Mack ay Building

338 Denali Street

Anchorage, Alaska 99501

Telephone: (907) 276-0508 


\section{ARIZONA}

- No enabling legislation regarding energy conservation standards for consumer products

- Waiting for Federal standards to be issued

- No voluntary energy conservation standards for consumer products

- Plans and Programs - The Arizona Office of Energy Policy and Conservation has used U.S. Department of Energy publications such as Tips for Energy Savers to inform citizens about energy conservation in the home. A brochure pertaining specifically to appliance use is being developed by the Public Information Staff for publication in 1980 .

Contact: Gerry Cunningham

Chief

Office of Energy

Office of Economic Planning and Development

Office of the Governor

Capitol Tower, Room 504

Phoenix, Arizona 85007

Telephone: (602) 255-5371. 


\section{ARKANSAS}

- No enabling state legislation regarding energy conservation standards for consumer products

- Waiting for Federal standards to be issued

- No voluntary energy conservation standards for consumer products

- Plans and Programs - Since the Arkansas Department of Energy was only created in July of 1979, public awareness programs are concentrating first in such areas as carpooling and home insulation.

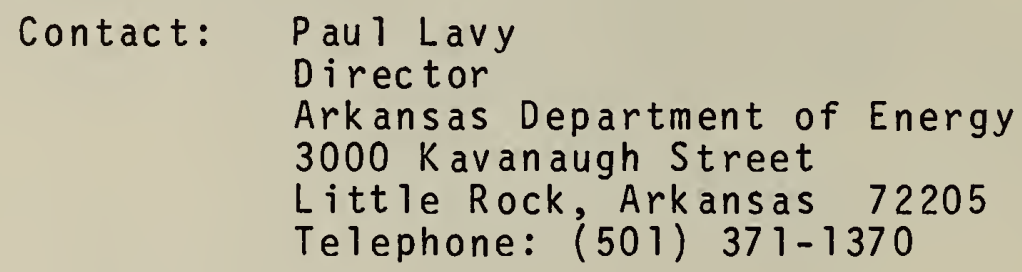


- In 1975 the California legis lature passed enabling legislation, the State Energy, Resources, Conservation, and Development Act (popularly known as the Warren-Alquist Act), creating the State Energy, Resources, Conservation, and Development Commission. Energy conservation standards regarding consumer products that were issued as a result of this legislation are the "Regulations for Appliance Efficiency Standards, "California Administrative Code: Title 20 Chapter 2, Sub-Chapter 4, Article 4, As amended JuTy 19, 1978.

The California Energy office has both regulatory and enforcement authority. Enforcement methods are as follows:

Manufacturers' self-certification through State Energy office directories which provide energy efficiency ratios of various appliances.

Appliances taken at random by State Energy Office personnel to an independent testing agency.

Spot checking and testing of appliances at various retail stores.

Non-compliance results in manufacturers paying for the costs of testing and taking steps to recertify the appliance.

- No voluntary energy conservation standards for other consumer products.

- Plans and Programs - Sections of individual California Energy office directories, stating the energy efficiency ratios for refrigerators and freezers, room and central air conditioners and water heaters, are listed as "Best Buys" and published by state utility companies for distribution with customer monthly billing statements.

Contact: Donald Watson

Acting Director

Conservation Division

Energy Resources Conservation and

Development Commission

1111 Howe Avenue

Sacramento, California 95825

Telephone: (916) 920-6091

NOTE: California's regulations were prescribed prior to January 1, 1978, and therefore will not be preempted by forthcoming Federal standards. 
- No enabling state legis lation regarding energy conservation standards for consumer products

- Waiting for Federal standards to be issued

- No voluntary energy conservation standards for consumer products

- Plans and Programs

- The Office of Energy Conservation published and distributed an Energy Scorecard, a self-audit form which allowed a consumer to determine the amount of energy used in home appliances.

- Fact sheets headed Energynote, produced by the office of Energy Conservation, provide homeowners with information to ass ist them in reducing energy consumption.

- The Office of Energy Conservation Residential Energy Conservation program encourages energy users to consider replacing old, inefficient heating equipment.

- To answer energy-related questions, a referral service is available to Colorado homeowners.

Contact: Buie Seawe 11

Director

Office of Energy Conservation, Office of the Governor

1600 Downing Street

Denver, Colorado 80218

Telephone: (303) 839-2507 


\section{CONNECTICUT}

- No enabling state legislation regarding energy conservation standards for consumer products

- Waiting for Federal standards to be issued

- No voluntary energy conservation standards for consumer products

- Plans and Programs

- Connecticut is a participant in the Energy Extension Service (EES) program, a pilot project sponsored by the U.S. Department of Energy, and distributes many of the DOE/EES publications regarding energy efficiency ratios of various appliances.

- Other information concerning appliance efficiency labeling is being developed by the Connecticut Department of Consumer Protection.

Contact: Thomas H. Fitzpatrick Under Secretary of Energy Energy Division Office of Policy and Management 80 Washington Street Hartford, Connecticut 06115 Telephone: (203) 566-5294 
- No enabling state legislation regarding energy conservation standards for consumer products

- Waiting for Federal standards to be issued

- No voluntary energy conservation standards for consumer products

- Plans and Programs - Through the Delaware Energy Office's Public Education Program, a heavy emphas is is placed on public awareness of energy conservation measures in general. An energy hot-line service is provided for specific information regarding energy efficiency ratios.

Contact: David Swazye

Acting Director

Delaware Energy office

P.0. Box 1401

114 W. Water Street

Dover, Delaware 19901

Telephone: (302) 678-5644 
- No enabling state legislation regarding energy conservation standards for consumer products

- Waiting for Federal standards to be issued

- No voluntary energy conservation standards for consumer products

- Plans and Programs

- Information on life cycle costing and the energy efficiency ratios of various appliances has been included in the brochures, workshops, and media campaigns developed by the Florida State Energy Office and the Regional Energy Action Committees.

- The State Energy office also works with the Florida Department of Agriculture and Consumer Services in promoting energy efficient purchasing information to F 1 orida consumers.

Contact: Lex Hester

Director

State Energy Office

Office of the Governor

301 Bryant Building

Tal1 ahassee, F1orida 32301

Telephone: (904) 488-6764 
- No enabling state legislation regarding energy conservation standards for consumer products

- Waiting for Federal standards to be issued

- No voluntary energy conservation standards for consumer products

- Plans and Programs

- The Energy Resources Division provides printed materials and sponsors a variety of home energy conservation programs with information regarding appliance operation, home heating and cooling, and water heaters.

- Through the Residential Energy Conservation Plan, public utilities are required to offer home energy audits.

- Fact sheets, covering such subjects as maintaining heating systems and conserving hot water, are developed and distributed through a contract with the University of Georgia's Cooperative Extension Service.

Contact: Mark Zwecker

Program Director

Energy Resources Division

Office of Planning and Budget

270 Washington Street, S.W.

At 1 anta, Georgia 30334

Telephone: (404) 656-3874 


\section{HAWA I I}

- No overall enabling legislation regarding energy conservation standards for consumer products.

However, a bill was passed by the Hawaiian Legislature which banned the sale and installation of gas appliances with pilot lights. Act 137 , Senate Bill No. 1598-78 was approved May 30, 1978. The Department of Planning and Economic Development has regulatory authority and is responsible for enforcing this Act.

- No voluntary energy conservation standards for other consumer products were implemented.

- Plans and Programs - The State Energy Office does not have any specific programs regarding consumer products.

Contact: Alfred S. Harris

Manager

State Energy Office

Department of Planning and Economic Development

P.0. Box 2359

Honolulu, Hawai 96804

Telephone: (808) 548-4080

NOTE: Any state requirement concerning gas pilot lights will automatically be preempted by Federal standards. 
- No enabling state legislation regarding energy conservation standards for consumer products

- Waiting for Federal standards to be issued

- No voluntary energy conservation standards for consumer products

- Plans and Programs

- Information on homeowner options for energy efficiency is distributed through state and federal materials and a monthly newsletter, The Energy Update. The Idaho Office of Energy staff, also offers personalized, technical assistance to consumers as part of Idaho's energy plan.

- The U.S. Department of Energy Extension Service (EES) program, provided outreach coordinators to encourage participation by Idaho citizens in energy audits and in the use of the Home Energy Savers' Workbook.

Contact: Robert Lenaghen

Acting Director

Idaho Office of Energy

State House

Bo ise, I daho 83720

Telephone: (208) 384-7724 


\section{$\underline{\text { ILLINOIS }}$}

- No enabling state legislation regarding energy conservation standards for consumer products

- Waiting for Federal standards to be issued

- No voluntary energy conservation standards for consumer products

- Plans and Programs - The Resource Conservation Division of the Institute of Natural Resources distributes a series of energy fact sheets which include information interpreting the energy efficiency ratio numbers on appliance labels.

Contact: Steve Thomas

Resource Conservation Manager

Institute of Natural Resources

$325 \mathrm{~N}$. Adams, Room 300

Springfield, Illino is 62706

Telephone: (217) 785-2378 
- No enabling state legislation regarding energy conservation standards for consumer products

- Waiting for Federal standards to be issued

- No voluntary energy conservation standards for consumer products

- Plans and Programs

- Through media campaigns, speaking engagements, and printed materials, the Indiana Energy Group attempts to create an awareness of appliance energy consumption.

- The Indiana Energy Group works with utility companies in promoting pilotless ignition appliances.

Contact: Clarence Broadus

Director

Indiana Department of Commerce

Energy Group

440 North Meridian Street

Indianapolis, Indiana 46204

Telephone: (317) 232-8940 
- No overall enabling state legislation regarding energy conservation standards for consumer products; however through the Iowa State Commerce Commission, state regulations exist pertaining to intermittent ignition devices. They are: Chapter $478 \mathrm{~A}$, Code of Iowa, "Gas Lamps and Pilot Lights" and Chapter 26, I owa Administrative Code, "Certification of Gas Appliances"

- The Iowa Commerce Commission has regulatory and enforcement authority for the regulations. Persons convicted of violating the provisions of Section $478 \mathrm{~A} .2$ shall be guilty of a simple misdemeanor.

- No voluntary energy conservation standards for other consumer products

- Plans and Programs

- Sponsored development of a computer-assisted home energy audit

- Developed and distributed a series of consumer brochures regarding the purchase of energy efficient appliances

- Energy workshops for the adult consumer are held throughout the state under contract with the Energy Resources Information Foundation (ERIF).

- The Home Energy Savers Manual with chapters pertaining to hot water heaters, air conditioners, and room heaters is available to Iowa consumers upon request.

$$
\begin{array}{ll}
\text { Contact: } & \text { Edward Stanek } \\
& \text { Director } \\
& \text { Iowa Energy Policy Council } \\
& \text { Capitol Complex } \\
& \text { Lucas Building, 6th Floor } \\
& \text { Des Moines, I owa } 50319 \\
& \text { Telephone: (515) 281-4420 }
\end{array}
$$

NOTE: Any state requirement with respect to prohibitions on gas pilot lights will automatically be preempted by Federal standards. 
- No enabling state legislation regarding energy conservation standards for consumer products

- Waiting for Federal standards to be issued

- No voluntary energy conservation standards for consumer products

- Plans and Programs - Through the Kansas Energy Office, material is distributed which offers suggestions for consumer buying, including explanations of the appliance energy efficiency ratios and the life cycle costing concept.

Contact: Joseph King

Director

Kansas Energy Office

503 Kansas Avenue

Topeka, Kansas 66603

Telephone: (913) 296-2496 
- No enabling state legislation regarding energy conservation standards for consumer products

- Waiting for Federal standards to be issued

- No voluntary energy conservation standards for consumer products

- Plans and Programs

- Designation of the Cooperative Extension Service to be the most significant delivery mechanism in accomplishing goals for home energy saving.

- Cooperation with the Continuing Education Offices of Kentucky's universities and colleges for the implemention of seminar programs addressing residential energy savings opportunities.

- Promotion of the life-cycle costing concept in appliance selection.

- Sponsorship through the Union of Kentucky Cooperative Extension Service, of a Special Home Energy Edition publication with suggestions regarding purchase and use of appliances.

Contact: Damon W. Harrison Commissioner

Department of Energy

Capitol Plaza Tower

Frankfort, Kentucky 40601

Telephone: (502) 564-7416 


\section{LOUIS IANA}

- No enabling state legislation regarding energy conservation standards for consumer products

- Waiting for Federal standards to be issued

- No voluntary energy conservation standards for consumer products

- Plans and Programs - Through public presentations and outreach materials, the Department of Natural Resources demonstrates the cost-savings of home energy conservation strategies.

Contact: T.C. Landrum

Director

Research and Development Division

Department of Natural Resources

P.0. Box 44156

Baton Rouge, Louisiana 70804

Telephone: (504) 342-4594 
MA INE

- No enabling state legislation regarding energy conservation standards for consumer products

- Waiting for Federal standards to be issued

- No voluntary energy conservation and efficiency standards for consumer products

- Plans and Programs - Public awareness regarding consumer products is promoted through information available at workshops and through the distribution of state and federal printed materials.

Contact: John Joseph

Director

Office of Energy Resources

Executive Department

55 Capitol Street

Augusta, Maine 04330

Telephone: (207) 289-3811 
- No enabling state legislation regarding energy conservation standards for consumer products

- Waiting for Federal standards to be issued

- No voluntary energy conservation standards for consumer products

- Plans and Programs

- As part of the Public Awareness Program of the Maryland State Energy P 1 an, consumers are encouraged to look for and take into consideration the energy efficiency ratios that appear on appliance labels.

- The Maryland Energy Office prepares and distributes appliance wattage charts (brand names not given) that, state the wattage of self-defrost and nonself-defrost, refrigerators and freezers, hair dryers, toasters, air conditioners, and several other appliances.

- The Maryland Energy Office maintains a toll-free energy hotline and conducts the Home Energy Savers' Program, which includes the distribution of various guidebooks to ass ist homeowners in saving energy.

Contact: Dr. Donald E. Milsten

Director

Maryland Energy Office

301 West Preston Street

Baltimore, Maryland 21201

Telephone: (301) $383-6810$ 


\section{MASSACHUSETTS}

- No enabling state legislation regarding energy conservation standards for consumer products

- Waiting for Federal standards to be issued

- No voluntary energy conservation standards for consumer products

- Plans and Programs - The Executive Office of Consumer Affairs and the Massachusetts utility companies provide consumers with information to ass ist them in home energy conservation measures and in the purchasing of energy-efficient appliances.

Contact: Joseph S. Fitzpatrick

Director

Massachusetts Office of Energy Resources

73 Tremont Street

Suite 700

Boston, Massachusetts 02108

Telephone: (617) 727-4732 
- No overall enabling state legislation regarding energy conservation standards for consumer products; however, a bill was enacted (Michigan Statute 429.352, 1978) "to provide for the labeling of appliances; to prohibit certain conduct; to prescribe the powers and duties of the public service commission; to provide for testing of appliances; and to provide for remedies and penalties."

- No state agency is charged with regulatory or enforcement authority for this legislation

- No voluntary energy conservation standards for other consumer products

- Plans and Programs - As part of the U.S. Department of Energy's pilot project, the Energy Extension Service (EES) program, Michigan provides to the consumer to 11 free energy information and a variety of publications concerning energy-efficient appliances. These

publications include: Common Sense Energy Tips, No More Hot Air About Room A ir Conditioners, and By the House ... By the Month... Energy Costs of Home Appliances.

Contact: Nancy Baerwaldt Acting Director Energy Administration

Michigan Department of Commerce

6520 Mercantile Way, Suite 1

P.0. Box 30228

Lansing, Michigan 48909

Telephone: (517) 373-0780

NOTE: Michigan Statute 429.352, referred to as the "Pilot Light Ban," may be amended in the current legis lative session. Proposed amendments would limit the scope of the Ban but also make any violation of the law a misdemeanor punishable by a fine of not more than $\$ 1,000$ or imprisonment of not more than 90 days, or both. 
- No overall enabling state legislation regarding energy conservation standards for consumer products; however, the Minnesota legislature has passed two bills pertaining to consumer products. They are: Minnesota Statute, Chapter $116 \mathrm{H}$, Subdivision 11, "Prohibition of Forced Air Furnaces, Cooking Appliances, and Clothes Dryers with Continuous Pilot Lights" and Minnesota Statute Chapter $116 \mathrm{H}$, Subdivision 10, "Standards for Air Conditioners"

- The Minnesota Energy Agency actively monitors and enforces compliance with the above regulations by sending a letter of warning to violators

- No voluntary energy conservation standards for other consumer products

- Plans and Programs

- The Minnesota Energy Agency maintains a toll-free telephone answering service as part of their Information Center.

- Pamphlets, fact sheets, and product literature regarding. various appliances are distributed to the public.

- A Home Energy Audit Conservation Guide, which discusses water heater modifications and includes energy and dollar-saving calculations, is available upon request.

Contact: A1 Johnson

Director

Minnesota Energy Agency

980 American Center Building

150 East Kellogg Boulevard

St. Paul, Minnesota 55101

Telephone: (612) 296-5120

NOTE: Any State requirement with respect to prohibitions on gas pilot lights will automatically be preempted by Federal standards. 


\section{MISSISSIPPI}

- No enabling state legis lation regarding energy conservation standards for consumer products

- Waiting for Federal standards to be issued

- No voluntary energy conservation standards for consumer products

- Plans and Programs

- An important part of the State Energy Plan is the Public Awareness Program with a full-time public information officer responsible for demonstrating to the public the how-to's of energy conservation.

- The Home Energy Conservation Program includes a campaign making an energy audit available to all homeowners through the State's major utility companies, followed by recommendations for home improvement and attempts to measure actual energy savings.

- A monthly newsletter, the Energy Gram, is copublished by the Mississippi Office of Energy and the Mississippi Energy Extension Center. In addition, a series of publications entitled Energy Tips, that appliances, is being designed for use by the media.

Contact: Peter J. Walley

Director

Office of Energy

Miss issippi Department of Natural Resources

Suite 228, Barefield Complex

$455 \mathrm{~N}$. Lamar Street

Jackson, Miss issippi 39201

Telephone: (601) 354-7406 
- No enabling state legislation regarding energy conservation standards for consumer products

- Waiting for Federal standards to be issued

- No voluntary energy conservation standards for consumer products

- Plans and Programs

- Through the Division of Energy's Comprehensive Public Education and Awareness Program, referred to as the Information Clearinghouse, state and federal publications as well as the Guide Sheets, developed by the Cooperative Extension Office of the

University of Missouri, are distributed to consumers for information regarding the purchase of energy efficient appliances.

- Other information concerning consumer products is available at the exhibits and demonstrations that are part of Missouri's Community Energy Fairs.

Contact: J.W. Abbott

Director

Division of Energy

Department of Natural Resources

P.0. Box 176

Jefferson City, Missouri 65102

Telephone: (314) 751-4000 
- No enabling state legislation regarding energy conservation standards for consumer products

- Waiting for Federal standards to be issued

- No voluntary energy conservation standards for consumer products

- Plans and Programs - The Conservation Division of the Montana Department of Natural Resources and Conservation does not have any specific programs related to consumer product energy conservation; however, this Division does promote a general conservation consciousness by ass isting the energy-related programs of the Human Resources Development Council, the Montana University System, citizen groups, utility companies, and adult educational groups.

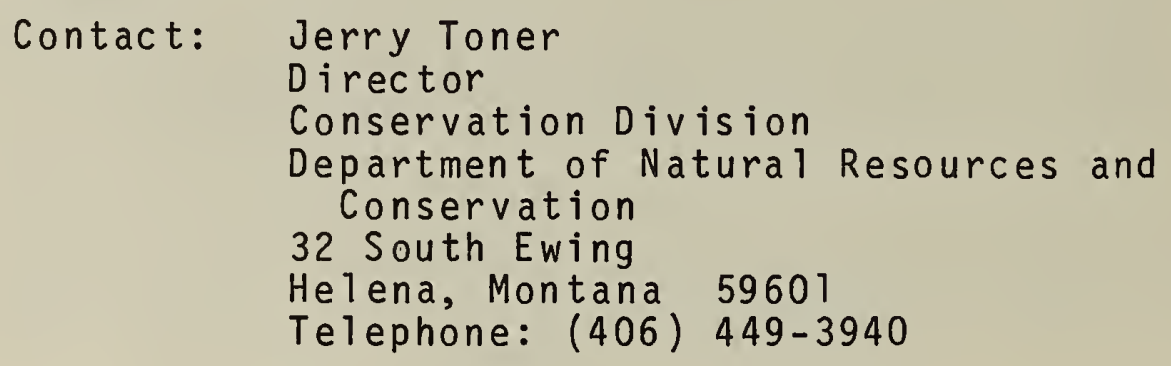




\section{NEBRASKA}

- No enabling state legislation regarding energy conservation standards for consumer products

- Waiting for Federal standards to be issued

- No voluntary energy conservation standards for consumer products

- Plans and Programs - The public is informed of such things as energy efficiency ratios of appliances and electric ignition systems for pilot lights through materials distributed by the Nebraska Energy Office and through programs and workshops sponsored with the help of the State's Home Extension agents.

$\begin{array}{ll}\text { Contact: } & \text { William H. Palmer } \\ & \text { Director } \\ & \text { Nebraska Energy Office } \\ & \text { P O. Box } 95085 \\ & \text { Lincoln, Nebraska } 68509 \\ & \text { Telephone: (402) } 471-2867\end{array}$


- The Nevada Legis lature has passed enabling

legislation, Nevada Revised Statute, Chapter 523, 1979,

in respect to authorizing the Director of the

Department of Energy to adopt regulations which

prohibit the sale of appliances with standing pilot

lights. Regulations, as a result of this

legislation, have not yet been written

- Waiting for Federal standards to be issued

- No voluntary energy conservation standards for consumer products

- Plans and Programs

- Through the U.S. Department of Energy publications such as Tips for Energy Savers and information available at Energy Expos, Nevada consumers become aware of purchasing guidelines for appliances and home energy conservation methods.

- The Nevada Department of Energy's public awareness campaign utilizes television and radio spots, direct mailings, newspapers, billboards, inserts in utility bills, and slide shows as methods of providing information to the public.

- Do-it-yourself home energy conservation kits are available to help individuals assess the methods by which energy consumption can be efficiently reduced.

Contact: Kelly Jackson

Director

Department of Energy

1050 E. William Street, Suite 405

Carson City, Nevada 89710

Telephone: (702) 885-5157 


\section{NEW HAMPSHIRE}

- No enabling state legislation regarding energy conservation standards for consumer products

- Waiting for Federal standards to be issued

- No voluntary energy conservation standards for consumer products

- Plans and Programs - Through workshops, seminars, printed materials, and a toll-free hotiine, the New Hampshire Council on Energy informs consumers about energy-saving appliances.

Contact: William R. Humm

Executive Director

Council on Energy

Executive Department

Office of the Governor

$21 / 2$ Beacon Street

Concord, New Hampshire 03301

Telephone: (603) 271-2711 


\section{NEW JERSEY}

- New Jersey has passed enabling legislation

(N.J.S.A. 52:27F-15) that directs the New Jersey

Department of Energy to "coordinate authority,

regulation, and planning by the state in energy

related matters."

- The state regulation pertaining to energy conservation standards for consumer products that was written as a result of this legislation is the "Retrofitting of Gas Pilot Lights," N.J.A.C. 14A:3-6.1-5.

- The New Jersey Department of Energy has both regulatory and enforcement authority; however, the proposals that were submitted by the state utility companies in regard to this regulation were rejected and $h$ ave not as of this date been resubmitted. Therefore, the regulation is not in effect.

- No voluntary energy conservation standards for other consumer products

- Plans and Programs

- The cornerstone of the New Jersey Energy Master PIan is informing consumers of the "relative operating-cost-saving merits of each appliance," not policing individual consumption habits. The monitoring of manufacturers is therefore essential to New Jersey's conservation plan.

- The New Jersey Department of Energy's Energy Exchange publications include articles regarding the energy efficiency ratios of various appliances. What to Do: New Jersey Home Energy Savings Workbook \# 1 is another publication prepared by the New Jersey Department of Energy.

Contact: Joel R. Jacobson

Commissioner

Department of Energy

101 Commerce Street

Newark, New Jersey 07102

Telephone: (201) 648-2744

NOTE: New Jersey identifies itself as the first state to establish its Department of Energy as a cabinetlevel agency. 
NEW MEXICO

- No enabling state legislation regarding energy conservation standards for consumer products

- Waiting for Federal standards to be issued and is currently reviewing California's standards

- No voluntary energy conservation and efficiency standards for consumer products

- Plans and Programs - As a participant in the Energy Extension Service (EES) program, a pilot project sponsored by the United States Department of Energy, the New Mexico Energy office is providing information regarding appliance labeling with DOE/EES printed materials and through a toll-free energy hot line.

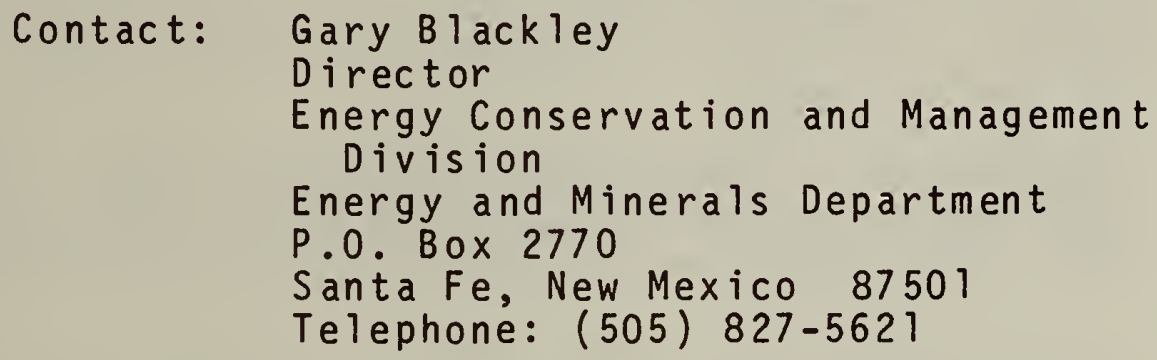


- Enabling legislation known as the New York Energy Law (Consolidated Laws of New York, Laws 1976, Chapter 819, Section 2) created the New York State Energy Office and gave that agency the authority to issue the following regulations: Energy Efficiency Standards for Air Conditioners, Article 9-109 and Energy Efficiency Standards for Water Heaters, Article 16-108

- The New York State Energy Office has both regulatory and enforcement authority. Since the above energy conservation standards are primarily self-regulatory, enforcement is carried out by sending a letter from the New York State Energy office to the appropriate company or manufacturer.

- No voluntary energy conservation standards for other consumer products

- Plans and Programs

- Through public service announcements concerning new regulations, consumers are alerted to the coefficient of performance standards and the energy efficient ratios.

- An energy hotline is maintained and state and federal publications that include home energy saving tips are available to the public.

- A hand-held fan with the energy efficent ratios of various appliances printed on it was developed by the New York State Energy office and is distributed throughout the state.

Contact: James L. Larocca

Commiss ioner

New York State Energy Office

Agency Building 2, 10th Floor

Empire State Plaza

Albany, New York 12223

Telephone: (518) 474-8313 
- No enabling state legislation regarding energy conservation standards for consumer products

- Waiting for Federal standards to be issued

- No voluntary energy conservation and efficiency standards for consumer products

- Plans and Programs

- Through the Energy Awareness/Referral Service, various elements "... increase citizen awareness of the need to conserve and provide consumers with objective information on the best methods of doing so." These elements include media campaigns, home energy audits, a toll-free energy hotline, "Saving Energy at Home" workshops, energy exhibits and fairs and the distribution of energy-related materials.

- The North Carolina Energy Division cooperates with the Better Business Bureau in answering complaints about energy products or manufacturers.

Contact: James E. Gibson, Jr.

Director

Energy Division, Department of Commerce P.0. Box 25249

Raleigh, North Carolina 27611

Telephone: (919) 733-2230 


\section{NORTH DAKOTA}

- No enabling state legislation regarding energy conservation standards for consumer products

o Waiting for Federal standards to be issued

o No voluntary energy conservation standards for consumer products

- Plans and Programs - A statewide consumer education program regarding energy efficiency ratios and labeling of appliances is being discussed with the Consumer Affairs Office of the State Laboratories Department. The development of such a project would also involve personnel from the College of Home Economics of the North Dakota State University.

Contact: Clifford Ness

Director

North Dakota Office of Energy

1533 North 12th Street

B ismarck, North Dakota 58501

Telephone: (701) 224-2250 
- No specific enabling legislation regarding energy conservation standards for consumer products

- Waiting for Federal standards to be issued

- No voluntary energy conservation standards for consumer products

- Plans and Programs - The Ohio Department of Energy provides for the dissemination of general energy conservation information. The Ohio Energy Code gives the energy efficiency ratio of certain appliances, and it ass ists homeowners with reducing energy consumption.

Contact: Robert S. Ryan

Director

Ohio Department of Energy

State Office Tower, 34 th Floor

30 East Broad Street

Columbus, Ohio 43215

Telephone: (614) 466-3465 
- No enabling state legislation regarding energy conservation standards for consumer products

- Waiting for Federal standards to be is sued

- No voluntary energy conservation standards for consumer products

- Plans and Programs

- The OKlahoma Department of Energy sponsors "hands-on" training programs which identify energy-saving opportunities directly to the consumer.

- A computerized home energy survey service is provided.

- Printed materials such as Home Appliance Inventory and Measurements and Appliance Energy Consumption are distributed to the public.

Contact: Richard G. Hill

Director

Ok 1 ahoma Department of Energy

4400 North Lincoln Boulevard

Suite 251

Ok 1 ahoma City, Ok 1 ahoma 73105

Telephone: (405) 521-3941 


\section{$\underline{\text { OREGON }}$}

- No enabling state legis lation regarding energy conservation standards for consumer products

- Waiting for Federal standards to be issued

- No voluntary energy conservation standards for consumer products

- Plans and Programs - Home energy audits are encouraged, and an Energy Awareness newsletter is produced with the cooperation of the State Consumer Affairs Division.

Contact: Lynn Frank

Director

Department of Energy

Labor and Industries Building

Salem, Oregon 97310

Telephone: (503) 378-4128 


\section{PENNS YLVANIA}

- No enabling state legislation regarding energy conservation standards for consumer products

- Waiting for Federal standards to be issued

- No voluntary energy conservation standards for consumer products

- Plans and Programs - The Public Awareness Program of the Governor's Energy Council provides for the dissemination of information regarding consumer products. Brand names are not endorsed but through a toll-free energy hotline and printed materials, citizens can obtain answers pertaining to the energy efficiency ratios of various appliances.

Contact: Robert A. Shinn

Executive Director

Governor's Energy Council

Office of the Governor

$1625 \mathrm{~N}$. Front Street

Harrisburg, Pennsylvania 17102

Telephone: (717) 783-8610 


\section{RHODE ISLAND}

- No enabling state legislation regarding energy conservation standards for consumer products

- Waiting for Federal standards to be issued

- No voluntary energy conservation standards for consumer products

- Plans and Programs - Through printed materials, energy expos, and an information hotline, the Rhode Island Energy office encourages consumers to consider energy efficiency ratios when purchasing various appliances.

Contact: Bob Coffey

State Energy Coordinator Governor's Energy Office 80 Dean Street

Providence, Rhode Is land 02903

Telephone: (401) 277-3370 


\section{SOUTH CAROLINA}

- No enabling state legislation regarding energy conservation standards for consumer products

- Waiting for Federal standards to be issued

- No voluntary energy conservation standards for consumer products

- Plans and Programs - The South Carolina Division of Energy Resources does not have any specific consumer product energy conservation programs other than providing information regarding the insulation of home water heaters.

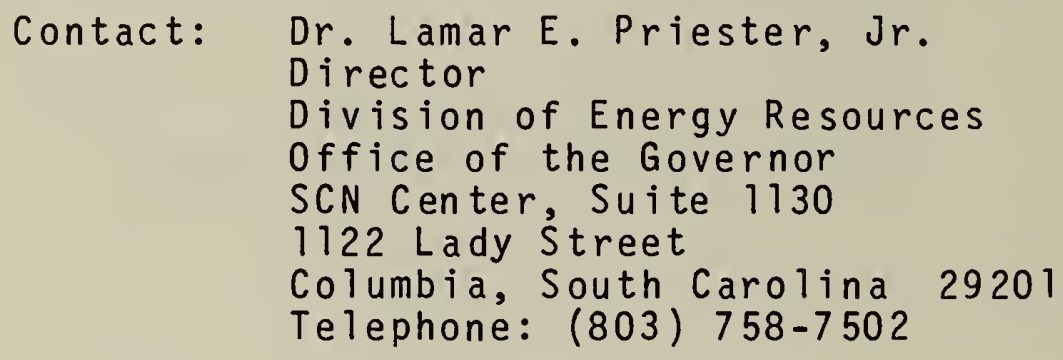




\section{SOUTH DAKOTA}

- No enabling state legislation regarding energy conservation standards for consumer products

- Waiting for Federal standards to be issued

- No voluntary energy conservation standards for consumer products

- Plans and Programs - Information regarding the efficient use of appliances is included in workshops sponsored by the State Office of Energy; purchasing guidelines can be found in the U.S. Department of Energy publications that are distributed to South Dakota consumers.

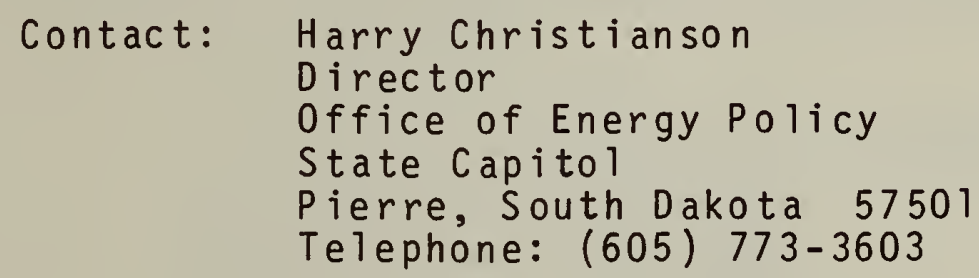

Contact: Harry Christianson

Director

Office of Energy Policy

State Capitol

Pierre, South Dakota 57501

Telephone: (605) 773-3603 


\section{TENNESSEE}

- No enabling state legislation regarding energy conservation standards for consumer products

- Waiting for Federal standards to be issued

- No voluntary energy conservation standards for consumer products

- Plans and Programs

- As part of the Tennessee State Energy Conservation Program, an Energy Information, Education, and Outreach Center (EIEOC) was established. The EIEOC provides information to energy consumers through a toll-free telephone hotline, special library resources, seminars and workshops, an awards program, technical assistance and a series of three-to-five minute audio tapes. The tapes include such topics as home heating, saving energy in the kitchen, and saving energy when using appliances.

- Printed materials regarding the energy efficiency ratios of appliances are provided through the Energy Extension Service (EES) program, a pilot project sponsored by the U.S. Department of Energy.

Contact: T.L. Guthrie

Acting Executive Director Tennessee Energy Authority 250 Capitol Hill Building Nashville, Tennessee 37219

Telephone: (615) 741-6671 
- No enabling state legislation regarding energy conservation standards for consumer products

- Waiting for Federal standards to be issued

- No voluntary energy conservation standards for consumer products

- Plans and Programs

- As a participant in the U.S. Department of Energy's pilot project, the Energy Extension Service (EES) program, Texas's energy plan emphasizes personalized information and technical assistance to help ensure consumer adoption of energy-saving techniques.

- Through energy audits, workshops, telephone consultations and the distribution of printed materials, conservation measures are encouraged which can result in reduced home heating and cooling energy requirements.

Contact: Edward Vetter

Executive Director

Texas Energy and Natural Resources

Advisory Council

411 West 13th, Suite 800

Austin, Texas 78701

Telephone: (512) 475-5407 
UTAH

- No enabling state legis lation regarding energy conservation standards for consumer products

- Waiting for Federal standards to be issued

- No voluntary energy conservation standards for consumer products

- Plans and Programs

- The Utah Energy office is currently preparing an appliance efficiency labeling workshop for appliance distributors and retailers.

- Through coordination with the state utility companies, printed materials regarding appliance energy efficiency ratios are developed and distributed.

- A telephone hotline, from which people can receive energy information, is maintained.

Contact: Jack Lyman

Director

Utah Energy office

231 East 400 South, Suite 101

Salt Lake City, Utah 84111

Telephone: (801) 533-5424 
- No enabling state legislation regarding energy conservation standards for consumer products

- The State Energy Office and the Attorney General's Office have discussed the issue of consumer product regulations but are waiting for the Federal standards to be issued before taking action

- No voluntary energy conservation standards for consumer products

- Plans and Programs - The HEAT (Home Energy Audit Teams) Project is co-sponsored by the University of Vermont Extension Service and the Vermont Energy office. HEAT offices are located throughout the state with personnel to provide information concerning energy conservation and to encourage home energy audits.

Contact: Ronald A. Allbee

Director

State Energy office

Pavilion Office Building

109 State Street

Montpelier, Vermont 05602

Telephone: (802) 828-2393 


\section{VIRGINIA}

- No enabling state legislation regarding energy conservation standards for consumer products

- Waiting for Federal standards to be issued

- No voluntary energy conservation standards for consumer products

- Plans and Programs

- Through their publications and the sponsoring of workshops such as "Home Energy Cost-Cutting Clinics," the Virginia Energy Division provides guidelines for selecting energy conserving materials and equipment.

- A toll-free telephone consulting service is maintained for the consumer to obtain energy information.

Contact: George L. Jones Coordinator

Energy Division

Office of Emergency and Energy Services

310 Turner Road

Richmond, Virginia 23225

Telephone: (804) 745-3245 


\section{WASHINGTON}

- No enabling state legislation regarding energy conservation standards for consumer products

- Waiting for Federal standards to be issued

o No voluntary energy conservation standards for consumer products

- Plans and Programs

- As a participant in the U.S. Department of Energy's

pilot project, the Energy Extension Service (EES)

program, many of Washington's public education

programs regarding home energy conservation come from

DOE/EES materials.

- The State Consumer Protection Division also distributes information regarding the energy efficiency ratios of various products.

Contact: Jack 0 . Wood

Director

State Energy office

1000 South Cherry Street

01 ympia, Washington 98504

Telephone: (206) 753-2417 
- No enabling state legislation regarding energy conservation standards for consumer products

- Waiting for Federal standards to be issued

- No voluntary energy conservation standards for consumer products

- Plans and Programs

- Distribution of the West Virginia Home Energy Saving Guide with such chapters as "Saving Energy with your Heating, Air Conditioning, and Water Heating," and "Buying a Room Air Conditioner."

- Distribution of Save Energy: Save Money! brochure with information pertaining to appliances.

- An energy hotline is maintained by the Fuels and Energy Office.

Contact: C. Joe Mullen

Director, Fuel and Energy office Governor's Office of Economic and Community Development

$12621 / 2$ Greenbrier Street

Charleston, West Virginia

25305

Telephone: (304) 348-8860 
- No overall enabling state legislation regarding energy conservation standards for consumer products; however, a bill was passed establishing a natural gas conservation program -- Wisconsin Statute 101.60, 1977, "Pilot Lights Prohibited on Gas Appliances."

- The State Department of Industry, Labor, and Human Relations has both regulatory and enforcement authority for this statute. A violation of the rule is subject to a forfeiture of not more than $\$ 400.00$ for each day of violation.

- No voluntary energy conservation standards for other consumer products

- Plans and Programs

- Energy Conservation Skills Shops provide supervised instruction regarding the best ways to insulate and monitor home heating system performance.

- Through Division of State Energy materials and programs, the life cycle costing concept is explained to Wisconsin consumers.

- Energy conservation contests are held to promote efficient energy practices within the home.

- Other consumer education materials and programs are made available through the Energy Extension Service (EES) pilot project sponsored by the U.S. Department of Energy. The management of Wisconsin's EES program is through the University of Wisconsin Extension office.

Contact: Willie Nunnery

Director

Division of State Energy

Department of Administration

1 West Wilson Street, Room 211

Madison, Wisconsin 53702

Telephone: (608) 266-8234 


\section{WYOMING}

- No enabling state legislation regarding energy conservation standards for consumer products

- Waiting for Federal standards to be issued

- No voluntary energy conservation standards for consumer products

- Plans and Programs - Consumer awareness of energy efficient appliances is promoted through information available at state energy fairs and through the distribution of U.S. Department of Energy publications.

Contact: Pamela Able

Director

Energy Conservation Office

Capitol Hill Office Building

Cheyenne, Wyoming 82002

Telephone: (307) 777-7131 
Bibliography - Introduction

This bibliography was prepared from published materials obtained from responsible state authorities. All state published materials that responded to the specific scope and criteria of this inquiry (see details in the Introduction) were requested. Most of the titles cited reflect state energy conservation plans, programs, and public education. DoE publications used by the states we re omitted from this bibliography. In some cases, the literature received by NBS mentioned collaboration with utility companies, universities, and the private sector. Literature to ass ist, the public in energy conservation from the states of Alaska, Arkansas, Connecticut, Illino is, Indiana, Kansas, Maine, Nebraska, Pennsylvania, South Dakota, and Wyoming is not included. These states were contacted, but material from them was not received. 
ALABAMA

A l abama Energy Management Board. Alabama Development Office. State Energy Conservation Plan for Alabama. Revised 1978.

AR I ZONA

Governor's Conference on Arizona Energy Policy. Final Report 1978.

Office of Economic Planning and Development. Proposal to the Department of Energy for 1979 Supplemental Energy Conservation P1an. January 1979.

Office of Economic Planning and Development. Proposal to the Department of Energy for 1979 Energy Conservation Plan. May 1979. Revision August 1, 1979 .

\section{CALIFORN IA}

California Energy Commission. California Administrative Code. Title 20, Chapter 2, Subchapter 4: "Energy Conservation." Article 4:

"Appliance Efficiency Standards." Amended July 19, 1978.

California Energy Commission. An Introduction to the 1979 Biennial Report of the California Energy Commission. Energy Choices for California. Looking Ahead. March 1979.

California Energy Commission. Publications catalog. May 1979. 404A:01 R3.

California Energy Commission. Publications catalog. Addendum. September 1979. 404A:26 R5.

California Energy Commission. Publications catalog. Index. October 1979 .

California Energy Commission. Publications catalog. Addendum. October 1979 .

California Energy Commission. Directory of Room Air Conditioners sorted by brand. May 1979. Revised June 1, 1979.

COLORADO

Office of Energy Conservation. Energy Conservation in Colorado. Proposed Programs for the 1979 Colorado Energy Conservation Plan. December 1, 1978 . 
DELAWARE

Delaware Energy Office. Executive Summary of State Energy Conservation Plan of Delaware. Plan for 1980.

FLOR IDA

Florida's Regional Energy Action! Committees. Public information program. Bylaws; adopted 12 July 1978.

GE OR GIA

Georgia Office of Energy Resources. Annual Report 1978.

HAWA I I

Hawaii Legislation. Act 137. Senate Bill No. 1598-78. An act relating to the banning of pilot lights on gas appiiances. May 30,1978 .

State of Hawaii Department of Planning and Economic Development. Energy Resources Coordinator. 1977 Annual Report. February 1978.

IDAHO

Office of Energy, State of Idaho. Idaho Energy Conservation Plan.

1979-1980 Revisions.

IOWA

Iowa Energy Policy Council. The Iowa Energy Conservation Plan:

1977-1980. March 28, 1977.

Iowa Energy Policy Council. The Iowa Energy Conservation Plan:

1977-1980. Appendix A through H. March 24, 1977.

Iowa Energy Policy Council. Energy: 1977. A Report of the Iowa Energy Policy Council.

Iowa Energy Policy Council. A Guide to Energy Efficient Heat Pumps. October 1977.

Iowa Energy Policy Council. Fifth Annual Report to the Legislature. January $15,1979$. 
Iowa Legislation. Chapter 478A. Code of Iowa. "Gas Lamps and Pilot Lights". May 1, 1979.

Iowa Legislation. Chapter 26. Iowa Administrative Code.

"Certification of Gas Appliances". July 11, 1979.

Iowa Energy Policy Council. Home Energy Savers Manual; Arco Publishing, Inc. New York. 1979.

\section{KENTUCKY}

Kentucky Department of Energy and Bureau of Energy Management. Kentucky Energy Conservation Plan. May 1979.

University of Kentucky. College of Agriculture. UKAG Report. Journal. Special Home Energy Edition. (n.d.)*

Kentucky Business Ledger. Journal Special Section: Energy in the 80 s. Crisis? Opportunity? November 1979.

LOUIS IANA

State of Louisiana. Department of Natural Resources. Louisiana Energy Conservation Plan 1979 (Third Year Base Plan). Tst Revision March 1979, 2nd Revision JuTy 1979.

State of Louisiana. Department of Natural Resources. State of Louisiana Supplemental Energy Conservation Plan (Third Year Plan). Revised Ju1y 1979.

MARYLAND

Department of Natural Resources. Maryland Energy Office Conservation Activities. October 1979.

Department of Natural Resources. Maryland Energy Office. Home Energy Saver. Appliance Wattage Chart. (n.d.)

Maryland Energy Office. The Neighborhood Energy Corps Program. Maryland Energy Saver. Journal. Vol. 1, No. 2.

\section{MASSACHUSETTS}

Massachusetts Energy Office; Better Home Heat Council, Inc. Information pamphlet: Are you burning money in the basement?. (n.d.)

Massachusetts Energy Office. Information pamphlet: How to Cut Fuel Bills in Apartments. (n.d.) 


\section{MICHI GAN}

State of Michigan. Enrolled House Bill 4126. An Act to prohibit sale of gas appliances with continuously burning pilot light except water heaters and appliances using liquefied gas. Legislature, Regular Session of 1979.

Michigan Department of Commerce. Energy Administration, Energy Extension Service. Energy dispatch: Energy Costs of Home Appliances. August 1978 .

Michigan Department of Commerce. Energy Administration. Report on Status of Michigan Energy Legislation. October 5, 1979.

Michigan Department of Commerce. Energy Administration. Energy Extension Service. Pamphlet: Common Sense Energy Tips. (n.d.)

Michigan Department of Commerce, Energy Administration. Energy Extension Service. Energy dispatch: No More Hot Air About Room Air Conditioners. (n.d.)

Michigan Department of Commerce Energy Administration, Energy Extension Service. Energy dispatch: Which Fuel to Choose?. (n.d.)

Michigan Department of Commerce. Energy Administration. Energy Extension Service. Information sheet. (n.d.)

Michigan Department of Commerce. Energy Administration. Energy Extension Service. Brochure: Tol1-Free Energy Information Service. $\left(n . d_{.}\right)$

Michigan Department of Commerce. Energy Administration. Brochure: How Michigan is helping itself save energy. (n.d.)

MINNESOTA

State of Minnesota. Minnesota Energy Agency. Modified State Energy Conservation Plan 1979.

Minnesota Energy Agency. Minnesota Statute, Chapter $116 \mathrm{H} .12$. Energy Conservation Subdivision 10. Standards for air conditioners. 1978 .

Minnesota Energy Agency. Minnesota Statute, Chapter 116 H. 12. Subdivision 11. Prohibition of forced air furnaces, cooking appliances and clothes dryers with continuously burning pilot lights. 1979.

MI SS I SS IPP I

Mississippi Fuel and Energy Management Commission. Energy Conservation Plan for the State of Mississippi. $197 \overline{9}$ 
Missouri Department of Natural Resources. Division of Energy. Summary of Division of Energy Programs. November 1979.

MON TANA

The Montana Energy and MHD Research and Development Institute, Inc. The Montana Energy Conservation Plan. Submitted to The Montana Energy Advisory Council. March 1977. Revised June 1977.

NE VADA

Nevada Department of Energy. Nevada Public Service Commission. Summary of Nevada State Energy Conservation Plan. ( $\left.n . d_{.}\right)$

Nevada Legislation. Senate Bill No. 458. Committee on Commerce and Labor. Section 1. Chapter 523 of NRS Amendment. An Act relating to energy; authorizing the director of the department of energy to adopt regulations prohibiting the sale of appliances with continuously burning pilot lights (with exceptions).

Nevada Legislation, Senate Bill No. 15. Committee on Government Affairs. Section 1. Chapter 523 of NRS Amendment. An Act for the conservation of energy by regulation for a 11 buildings, the construction of which is commenced on or after July 1, 1978. The standards apply to air conditioning equipment; water heating equipment, etc.

NEW HAMPSHIRE

Governor's Council on Energy. New Hampshire Energy Conservation Plan. Executive Summary. (n.d.)

Governor's Council on Energy. The Division of Human Resources, The Claremont Energy Project. Cooperative Extension Service.

Information sheet: \$avenergy; Help! Where to Go for Information and Assistance. (n.d.)

Governor's Council on Energy. The Division of Human Resources. The Claremont Energy Project. Cooperative Extension Service.

Information sheet: \$avenergy; Heating with Wood. (n.d.)

Governor's Council on Energy, The Division of Human Resources. The Claremont Energy Project. Cooperative Extension Service.

Information sheet: \$avenergy; How to Cut your Hot Water Expenses. (n.d.)

Governor's Council on Energy. The Division of Human Resources. The Claremont Energy Project. Cooperative Extension Service. Information sheet: \$avenergy; Home Management Tips to Cut Energy Costs. (n.d.) 
Governor's Council on Energy. The Division of Human Resources. The Claremont Energy Project. Cooperative Extension Service.

Information sheet: Tried \& True: Inexpensive ways to Beat the Cold. $(n . d$.

Governor's Council on Energy. The Division of Human Resources. The Claremont Energy Project. Cooperative Extension Service.

Information sheet: \$avenergy: 0il Burner Efficiency. (n.d.)

Governor's Council on Energy. Information brochure. How a simple tune-up can increase your oil burner efficiency. (n.d.)

NEW JERSEY

State of New Jersey. Department of Energy. The New Jersey Energy Master Plan. October 1978.

State of New Jersey. Department of Energy. State Energy Conservation Regulations. Adopted August 2, 1978. Re issued September 8, 1978.

New Jersey Department of Energy. Energy Exchange. Vol. 2, No. 3, May 1979.

New Jersey Department of Energy. Energy Exchange. Vol. 2, No. 4, June 1979.

New Jersey Department of Energy. Energy Exchange. Vol. 2, No. 5, July-August 1979.

New Jersey Department of Energy. Energy Exchange. Vol. 2, No:- 7 , October 1979.

New Jersey Department of Energy. A Practical Guide to Tenant Conservation. (n.d.)

New Jersey Department of Energy. Energy, Food and You. Brochure. $(n . d$.

New Jersey Department of Energy. What to Do: New Jersey Home Energy Savings Workbook \#1." PamphTet. (n.d.)

NEW MEXICO

State of New Mexico. Energy and Minerals Department. New Mexico State Energy Plan. December 1978. 
NEW YORK

New York Legislation E403.13 (7813.18) 9 NYCRR. HVAC Equipment Performance Requirements.

New York Legislation E404.0 (7813-4) 9 NYCRR. Service Water Heating.

New York Legislation E404.1 (7813.19) 9 NYCRR. General.

New York Legislation E404.2 (7813.20) 9 NYCRR. Scope.

New York Legislation E404.3 (7813.21) 9 NYCRR. Water Heaters, Storage Tanks, Boilers and Piping.

New York Legislation E404.4 (7813.22) 9 NYCRR. Insulation.

New York Legislation E404.5 (7813.23) 9 NYCRR. Temperature Controls.

New York Legislation. Official Compilation of the Codes Rules and Regulations. Title 9, Executive; Subtitle BB, State Energy Office; Chapter II, Codes and Standards; Subchapter C, Appliance Standards; Part 7826.1. Energy Efficiency Standards for Residential and Commercial Water Heaters.

New York State, Energy Research and Development Authority. NYSERDA Annual Report, 1979.

McKinney's Consolidated Laws of New York. Annotated. Book 17 1/4. Energy Law. Effective 1976. 1978 Amendments. West Pubtishing Co. 1978 .

New York State Energy Office. New York State Energy Conservation Plan. Volume 1. 1977-1980.

NORTH CAROLINA

North Carolina Department of Commerce, Energy Division. North Carolina Energy Conservation Plan. 1980.

NORTH DAKOTA

State of North Dakota. Executive Order 1977-9, Energy Conservation P1ans. August 12, 1977.

North Dakota Office of Energy Management and Conservation. Home Energy Audit. (n.d.)

State of North Dakota. Procurement Program for Appliances. (n.d.) 
OHIO

Ohio Department of Energy. The Ohio Energy Conservation Plan. May 1 , 1979.

OKLAHOMA

Ok 1 ahoma Department of Energy. A Guide to Energy Conservation Activities and Services. 1979-1980. May 1979.

Oklahoma Department of Energy. Oklahoma Energy Conservation Plan. 1979 Revision.

Oklahoma Department of Energy. Information pamphlet: Energy Conservation and $0 k 1$ ahoma. (n.d.)

OREGON

Oregon Legislation. House Bill 2147. Chapter 164. An Act relating to energy conservation. Oregon Legislative Assembly. 1979. Regular Session.

Oregon Department of Energy. Oregon Energy Conservation Plan. 1979. Oregon Department of Energy. Information pamphlet: Saving Energy and Money Makes Sense. Weatherization and Alternate Resource Incentives for Oregonians. (n.d.)

Oregon Department of Energy. Information pamphlet: Weatherization: One Step at a Time. (n.d.)

\section{RHODE ISLAND}

Rhode Island State Energy Conservation Plan. Excerpt; Fact sheet:

"Cost to Run Appliances". 1979.

\section{TENNESSEE}

Tennessee Energy Authority (TEA). Tennessee Energy Conservation $P 1$ an Report in Response to the Federal Energy Policy and Conservation Act of 1975. Public Law 94-163. A Summary.

TEXAS

Texas Energy and Natural Resources Advisory Council and Center for Energy and Mineral Resources. Texas A\&M University. Proposed Texas Energy Extension Service Three Year Plan. October 17, 1979. 
UTAH

State of Utah. Utah Energy Office. Annual Program Report of the Energy Conservation and Development Council. December 1978.

State of Utah. Utah Energy Office. University of Utah. Utah Engineering Experiment Station. 1978 Program for Energy Conservation in Utah, Executive Summary.

State of Utah. Utah Energy office. Energy Conservation and Development Counci1. The 1979 Program for Energy Conservation in Utah.

VERMONT

Vermont State Energy Office. Pamphlet: Cutting Fuel Costs in Your oil Fired Boiler. (n.d.)

Vermont State Energy Office. Pamphlet: Wood Fuel Facts. (n.d.)

Vermont State Energy Office. University of Vermont Extension Service. Pamphlet: Saving Energy Saves $\$$. (n.d.)

Vermont State Energy Office. Pamphlet: Energy Performance Audit. (n.d.)

Vermont State Energy Office. Information sheet: Insulating Your Electric Hot Water Heater. (n.d.)

Vermont State Energy office. Information sheet: Information on Federal and State Energy Income Tax Credits. (n.d.)

"Woodburning." Reprint from: Blair and Ketchum's Country Journal. October 1976 .

VIR GIN IA

Virginia Energy Office. Amendment to the State Energy Conservation Plan Report for the Commonwealth of Virginia. Part IV Program Narrative.

State Office of Emergency and Energy Services. Division of Energy. Virginia Energy Management and Conservation Supplemental Plan. Part IV Program Narrative. 1978 Modifications.

\section{WASHINGTON}

Washington State Energy Office. Washington State Application for State Energy Conservation and Supplemental State Energy Conservation Energy Program. April 30, 1979. 
West Virginia Office of Economic and Community Development. Fuel and Energy Division. West Virginia Energy Conservation Plan. A Response to the Energy Policy and Conservation Act. May 23, 1977.

West Virginia Fuel and Energy office. West Virginia Supplemental Energy Conservation Plan. July $22,1977$.

Community Services Administration. Pamphlet: Save Energy - Save Money. Revised Edition. CSA Pamphlet 6143-5. August 1977.

West Virginia Fuel and Energy Office. West Virginia Home Energy Saving Guide. Arco Publishing, Inc. New York. 1979.

Monongahela Power. A Part of the Allegheny Power System. Pamphlet: Is There an Energy Crisis. RS-30-5000. 2-77.

State of West Virginia. List of Publications Available Through the West Virginia Fuel and Energy Office. Fuel and Energy. (n.d.)

\section{WISCONS IN}

State of Wisconsin Legislation. 1977 Assembly Bill 353. Chapter 369. Laws of 1977 , \#101.60 "Pilot lights prohibited on gas appliances," and \#196.97 "Nonessential uses of natural gas".

Wisconsin State Energy Office. Wisconsin State Energy Conservation Plan. Summary. 1979. 


